\title{
Edyta GRYKSA
}

Uniwersytet Śląski

\section{VIR ROMANUS - PROBUS, HONESTUS, BENEVOLUS? POSTULOWANE CECHY RZYMIANINA A WIZERUNKI WŁADCÓW DYNASTII JULIJSKO-KLAUDYJSKIEJ W WYBRANYCH PASSUSACH DZIEL ANTYCZNYCH ${ }^{1}$}

\author{
VIR ROMANUS - PROBUS, HONESTUS, BENEVOLUS? \\ POSTULATED FEATURES OF A ROMAN AND THE IMAGES \\ OF THE JULIO-CLAUDIAN DYNASTY RULERS IN SELECTED \\ PASSAGES OF ANCIENT WORKS
}

The aim of the article is an attempt to present a dichotomic image of the Roman ruler. It is concentrated on traditional features, understood as postulated in relation to person in power, such as justice, honesty, modesty and self-control. All of them belong to the canon of virtutes Romanae, and obedience toward them was characteristic of Roman society until the fall of Carthage. Along with its fall, the disappearance of true morality can be observed. The important turning point there is the reign of Augustus who, by undertaking the revival of old values, introduces a new order to the state. The article describes the rulers of the Julio-Claudian dynasty, and the emphasis is placed on a dualistic image of their behaviour (positive versus negative) presented in ancient texts by Tacitus, Suetonius, Velleius Paterculus and Florus. emperors

Keywords: Julio-Claudian dynasty, Roman virtues, historiographical images of the Roman

Tradycja postrzegania człowieka przez pryzmat ideologii i przyjętych w danym społeczeństwie zasad sięga już czasów antycznych. Rzymianin miał cechować się m.in. skromnością (vir probus), uczciwością (honestus) czy życzliwością

${ }^{1}$ Pragnę wyrazić podziękowania dla Fundacji z Brzezia Lanckorońskich. Ukończenie prac nad artykułem było możliwe dzięki badaniom przeprowadzonym w brytyjskich ośrodkach naukowych. Zagraniczny pobyt naukowy został sfinansowany przez Fundację na podstawie decyzji nr 41-3/19. 
(benevolus). Cnoty te zaliczano do kanonu tzw. virtutes Romanae. Obok literackich passusów, w których chwalona jest odwaga żołnierzy i ich gotowość do poświęcenia życia w imię najwyższych wartości, obok fragmentów panegiryzujących pracowitość rzemieślników czy erudycję mówców, znajdujemy także relacje historiografów i biografów ukazujące inne oblicze Rzymianina. Analizując źródła i oceniając poszczególne postaci ze współczesnego punktu widzenia należy jednak brać pod uwagę elitarny postulat etyczny, a w przypadku relacji historiograficznych możliwe zabiegi idealizowania przeszłości. Moralne i polityczne przekonania historyków niejednokrotnie wpływały na ton przekazywanych relacji, przedstawianą ocenę wydarzeń, a tym samym całą historię spisaną w ich dziełach. Badania ich treści w każdym przypadku powinny zatem bezpośrednio koncentrować się na szeroko pojętej tradycji kulturowo-społecznej, dzięki czemu uwydatnia się różnica między autorami obiektywnymi i subiektywnymi² (Gryksa 2017a: 55).

Celem niniejszego artykułu jest przedstawienie dychotomii zachowań rzymskich władców w odniesieniu do kanonu postulowanych cech, jakie powinny ich charakteryzować. Wyniki przeprowadzonych badań oparte są na analizie wybranych fragmentów dzieł historiograficznych okresu cesarstwa ${ }^{3}$, w których autorzy opisali nie tylko pozytywne i warte naśladowania zachowania władców, lecz także ich negatywne postawy kontrastujące z ideą vir Romanus. Próba komparatystyki wybranych wizerunków rzymskich cesarzy dynastii julijsko-klaudyjskiej pozwoli zbudować dualistyczny wizerunek antycznych cesarzy - z jednej strony przykładnych Rzymian i władców, z drugiej - ludzi skorumpowanych, żądnych władzy i zepsutych moralnie. Na potrzeby niniejszego artykułu wybrane zostały passusy dzieł Florusa (Epitome de Tito Livio), dzięki którym możliwe będzie nakreślenie sytuacji politycznej i postaw moralnych mieszkańców Rzymu w okresie od zarania dziejów aż do panowania Augusta. Panowanie Augusta oraz Tyberiusza zostaną ponadto przedstawione w oparciu o analizę dzieła Wellejusza Paterkulusa (w przypadku historii Tyberiusza, są to relacje naocznego świadka wydarzeń). Kluczowymi tekstami do przedstawienia charakterystyki cesarzy będą ponadto Żywoty Cezarów autorstwa Swetoniusza oraz Tacytowe Annales ${ }^{4}$. Florus i Sweto-

2 Vide etiam: Paul 2011; Grethlein 2013; Ankersmit 2002; Marincola 1997.

${ }^{3} \mathrm{~W}$ okresie cesarstwa zarysowują się wyraźne zmiany w pisarstwie historiograficznym. Historia perpetua ustępuje miejsca dziełom skoncentrowanym na wydarzeniach współczesnych. Zmiany dotyczą nie tylko stylu, który staje się krótki i zwięzły (plus significare quam loqui) oraz przeplatania narracji tekstowymi niezwykłościami (curiositates). W twórczości pisarzy tego okresu uwidacznia się wyraźny antropocentryzm. Wiele uwagi poświęca się panującym cesarzom. Odmiennie niż w przypadku cenionej przez Tacyta zasady obiektywizmu i opisywania wydarzeń bez gniewu i upodobania (sine ira et studio) twórcy tego okresu dają wyraz swojej służalczości (przede wszystkim w stosunku do panującego) lub nieskrywanej niechęci wobec cesarskich dworów. Należy zwrócić uwagę na fakt, że w tych właśnie czasach miało także miejsce groźne zjawisko prześladowania historyków, jak w przypadku Kremucjusza Kordusa czy Arulenusa Rustikusa. Cf. Lewandowski 2007: 241.

${ }^{4}$ Wybrane do analiz passusy wiążą się bezpośrednio z przedstawionymi we wstępie rzymskimi cnotami (virtutes) i sygnalizują pewne tendencje w obrębie szeroko rozumianej moralności antycznej. 
niusz uznani są w oparciu o naukowe dyskusje za twórców obiektywnych, którzy w swoich ocenach pozostają wolni od wyrażania własnych osądów i nie wahają się sięgać po silne argumenty i exempla. W ich przypadku ważna jest także wyraźna granica, jaką stawiają w historii rzymskiej w czasie upadku Kartaginy, o czym wspomnę w dalszej części artykułu. Wellejusz Paterkulus, opisując czasy sobie współczesne, przedstawia historię z punktu widzenia człowieka aprobującego daną formę ustroju i wiernego ówczesnej władzy. Obiektywny w swoich relacjach stara się pozostać Tacyt ${ }^{5}$, choć w jego przekazie widoczny jest wpływ tendencji politycznych i społecznych (Lewandowski 2007: 296). Sam historyk jest jednak świadom ograniczeń i specyfiki historiografii jego czasów, w których niemożliwe jest swobodne wyrażanie opinii, co z kolei przekłada się na opisywanie małostkowych faktów ${ }^{6}$. Relacje wspomnianych historyków pozwalają przedstawić wizerunki władców, którzy różnią się pod względem behawioralnym w zależności od przekonań autora dzieła. Wszystkie ich zachowania można jednak sprowadzić do analiz i komparacji na wspólnej płaszczyźnie jaką są postulowane cechy władców i zobrazować podział ich zachowań w kategoriach pozytywnych i negatywnych. Badania, których wyniki przedstawione zostały w niniejszym tekście, prowadzone były w oparciu o metody filologiczne, skupiające się na autorze danego przekazu wraz z jego celem? ${ }^{7}$.

Zgodnie $\mathrm{z}$ antyczną tradycją podstawę stabilności i ciągłości państwa rzymskiego stanowiła koncepcja obyczajów przodków (Zoch 2012: 134-135) znana jako mos maiorum, a sama postawa wzorowego Rzymianina wpisywała się w kanon virtutes Romanae ${ }^{8}$ zawartych pod ogólnym pojęciem humanitas. Zaliczano tutaj takie zalety jak np. iustitia, magnanimitas, aequitas, moderatio czy fides (Baumann 2006: 6). Sama tradycja obyczajów przodków, uznawana za podstawę stabilności i ciągłości państwa rzymskiego, była kwestią dynamiczną, którą na szeroką skalę dostosowywano do rozwijających się warunków społeczno-politycznych (Wilkinson 2012: 17). Wśród historiografów panowało przekonanie, że wartości te pielęgnowano w początkowych okresach rozwoju państwa, kiedy prowadzone wojny miały na celu obronę terytorium przed najazdem wroga. Wspomina o tym Florus w Epitome de Tito Livio, który, opisując okres młodości narodu, podkreśla istotę walk o suwerenność państwa i wolność społeczną (Gryksa 2017a: 32):

Bronił on [sc. naród rzymski] bowiem wolności, obyczajności, godności urodzenia, majestatu i dostojeństwa urzędów. Niczego jednak nie bronił tak gorliwie jak wolności i nie dał się za nią

${ }^{5}$ W myśl zasady sine ira et studio (Ann. 1, 1, 3) czy neque cum amore [...] et sine odio (Hist. 1, 1,3) stawiając sobie za cel przekazanie wartościowych nauk moralnych dla potomnych (Ann. 3, 65, 1; 4, 33, 2; 6, 7, 5; Hist. 4, 33, 2). Vide: Gryksa 2017a: 51.

${ }^{6}$ Nobis in arto et inglorius labor (Lewandowski 2007: 296, przyp. 71; vide etiam Pigoń 1996).

7 Więcej na temat metod filologicznych i ich zastosowania: Heck 2009.

${ }^{8}$ Ich wyliczenie znajdujemy w De legibus Cycerona (2, 28). 
w żaden sposób przekupić, chociaż jak to bywa w wielkim i z dnia na dzień powiększającym się narodzie, pojawiali się od czasu do czasu zbrodniczy obywatele ${ }^{9}$ [tłum. I. Lewandowski].

Akcentując charakterystyczną dychotomię sprawiedliwość - zbrodniczość Florus stawia wyraźną granicę między okresami, w których społeczeństwo rzymskie żyło zgodnie z ogólnie przyjętymi, słusznymi i sprawiedliwymi zasadami oraz kiedy kanon cnót ustępuje miejsca występkowi i niesprawiedliwościom:

Dotąd naród rzymski był wspaniały, wyjątkowy, pobożny, święty i wielkoduszny; w dalszych latach tego okresu z powodu występków mnożących się wraz ze wzrostem terytorialnym ukazała się zarówno jego wielkość, jak i zamęt i haniebne czyny [Flor. 1, 34, 1; thum. I. Lewandowski].

Wraz z upływem czasu daje się zauważyć zmiana w zachowaniu rzymskich obywateli. Punktem zwrotnym, jaki niejednokrotnie wskazują historycy ${ }^{10}$, jest przede wszystkim upadek Kartaginy (146 r. p.n.e.) - zanik strachu przed zewnętrznym wrogiem (metus hostilis) sprzyja nieprawości:

Boje z Kartaginą zaczęli nasi przodkowie za konsulatu Klaudiusza i Fulwiusza [...]. Odtąd przez lat sto dwadzieścia między obu narodami trwała bądź wojna, bądź stan pogotowia wojennego, bądź nie budzący zaufania pokój. Rzym nawet wtedy, gdy pokonał już cały świat, nie wierzył w swe bezpieczeństwo, jeśliby ocalało gdzieś imię Kartaginy jako miasta żywych. Do tego stopnia nienawiść wyrosła z rywalizacji i walk trwa dłużej niż lęk; nie wygasa nawet wobec pokonanych i dopóki istnieje, zachowuje swój mściwy charakter ${ }^{11}$ [tłum. E. Zwolski].

Opinie o tym, że nawet najsilniejsze i najtrwalsze państwo ulegnie z czasem rozkładowi wyrażało wielu starożytnych myślicieli, w tym Platon (Plt. 546A) czy Polibiusz $(6,51,4)$. Szacunek do mores maiorum, przekazywany z pokolenia na pokolenie, uczył młodzież optymalnego postępowania. Opierając się na zasadach pewnej schematyczności stawał się dla państwa gwarantem bezpieczeństwa (Polo 2003: 13-17). Świat rzymski czerpiąc korzyści z niesprawiedliwości, oszustw, korupcji z czasem stał się dla siebie poważnym zagrożeniem. Wybuch wojen do-

${ }^{9}$ Flor. 1, 17, 5-6: Si quidem nunc libertatem, nunc pudicitiam, tum natalium dignitatem, tum honorum decora et insygnia vindicavit, interque haec omnia nullius acrior custos quam libertatis fuit, nullaque in pretium eius largitione corrumpi, cum ut in magno et in dies maiore populo interim perniciosi cives existerent.

${ }^{10}$ Sal. Iug. 41, 2: [...] obawa przed nieprzyjacielem zewnętrznym utrzymywała społeczeństwo w dobrych obyczajach. Lecz kiedy ten strach opuścił serca, wtargnęły oczywiście te wady, które są ulubionymi towarzyszkami powodzenia: rozwiązłość i buta [tłum. K. Kumaniecki].

11 Vell. 1, 12: Hunc finem habuit Romani imperii Carthago aemula, cum qua bellare maiores nostri coepere Claudio et Fulvio consulibus ante annos ducentos nonaginta duos, quam tu, M. Vinici, consulatum inires. Ita per annos centum et viginti aut bellum inter eos populos aut belli praeparatio aut infida pax fuit. Neque se Roma iam terrarum orbi superato securam speravit fore, si nomen usquam stantis maneret Carthaginis: adeo odium certaminibus ortum ultra metum durat et ne in victis quidem deponitur neque ante invisum esse desinit quam esse desiit. 
mowych i brak jedności w ówczesnym społeczeństwie skutecznie osłabił czujność narodu, prowadząc do upadku państwa. Na kartach jego historii zapisało się tymczasem wielu bohaterów, których postawy wobec ogólnie przyjętej tradycji i stosunku do virtus Romana i mos maiorum pozwalają zbudować dychotomiczny obraz Rzymianina. Obok zachowań godnych naśladowania można w nim wyodrębnić cechy i działania dalekie od tych, których oczekiwano od vir Romanus.

Przykłady obywateli, którzy do dziś uznawani są za wzór rzymskich cnót i wartości można mnożyć ${ }^{12}$. Obok zwyczajnych mieszkańców Rzymu, urzędników, kapłanów czy wojowników, pojawiają się najważniejsze postaci w państwie rzymskim - cesarze. Wśród nich reprezentanci dynastii julijsko-klaudyjskiej wraz z Augustem, który panował od 16 stycznia 27 r. p.n.e., aż do swojej śmierci w dniu 19 sierpnia 14 r. n.e. Po wielu latach zamieszek i nieszczęść, bratobójczych wojen prowadzących do zniszczenia państwa, nastąpił stopniowy powrót państwa do dawnej świetności. Przyczyn upadku Republiki upatrywano się przede wszystkim w zaniedbaniu zwyczajów przodków (mores maiorum). Tworzone w starych pałacach wizje prostoty i pobożności starych Rzymian, bezinteresowność przywódców politycznych czy gotowość chłopskiego społeczeństwa do poświęceń stały się już tylko nic nie znaczącą wizją (Zanker 1999: 12). August, zwycięzca bitwy pod Akcjum, uznawany był za nowego Romulusa. Podobnie jak Kamillus, który ocalił miasto przed najazdem Gallów i zyskał miano Romulus ac parens patriae conditorque alter urbis (Liv. 5, 49, 7), tak Oktawian, ocaliwszy Rzym przed dominacją Antoniusza i Kleopatry, zasłużył sobie na identyczne miano. August rozważał przybranie imienia Romulus, jednak w 27 roku p.n.e., ze względu na konotacje z władzą królewską, nie pasowało to do ówczesnej koncepcji. Termin Augustus był natomiast przymiotnikiem o szerokim polu semantycznym - oznaczał kogoś dostojnego, czcigodnego i świętego. Ponadto posiadał związek z czasownikiem augere (powiększać) oraz skojarzenia z funkcjami kapłańskimi $(\text { augur })^{13}$. Sam więc wybór imienia otaczał Augusta aurą wyjątkowości i wywyższenia. Po zdobyciu władzy w 31 roku p.n.e. cesarz podjął konsekwentną walkę z dotychczasowym ustrojem. Jego program kulturalny miał na celu dogłębną odnowę moralną i spowodował rzeczywistą przemianę społecznej mentalności. Zamiast autogloryfikacji rywalizujących wodzów ustanowiono oddawanie czci wybranego przez bogów władcy, wprowadzono zasady zwalczania państwowego

12 Zaliczyć należy tutaj np. Cyncynata, Marka Furiusza Kamillusa czy Publiusza Decjusza Musa.

${ }^{13}$ Etymologiczne powiązania $\mathrm{z}$ czasownikiem augere odnoszą się explicite do ekspansji rzymskiego imperium. Z kolei derywowanie terminu od łacińskiego augurium wynika ze swoistej profetyczności państwa rzymskiego. Państwo sukcesywnie zdobywające supremację nad światem uznawano za objęte boską ochroną i kierowane w myśl religijnych przesłanek. Warto podkreślić, że pierwszym narodem podbitym przez armię Augusta byli Garamaci (Garamantes - greckie mantis oznacza proroka, wieszczka. Kapłani - wieszczkowie odgrywali istotna rolę w starożytności, kiedy każde ważniejsze wydarzenie poprzedzano wróżbami). Cf. Zanker 1999: 103; Paschalis 1997: 240; Gryksa 2017b: 17-26. 
przepychu (publica magnificentia), ustanowiono również ruch odnowy religijnej i moralnej (Zanker 1999: 12-13). August dążył do umocnienia swojej pozycji głosząc hasło Pax Augusta ${ }^{14}$ - pokoju w granicach państwa rzymskiego.

Uznanie i pochwałę epitomatora August zyskuje jako odnowiciel rzymskich ideałów, który wprowadził ład w państwie:

Należy się jednak cieszyć, że w czasie tak wielkiego zamętu władza spoczęła w rękach Cezara Augusta Oktawiusza, który swoim rozumem i zręcznością doprowadził do ładu skołatany organizm państwowy. Bez wątpienia nie można by w nim było zaprowadzić jedności i zgody, gdyby nie kierowała nim wola jednego władcy, będącego tak jakby jego duszą i rozumem ${ }^{15}$ [tłum. I. Lewandowski] ${ }^{16}$.

W powyższym passusie Florus podkreśla zalety i znaczenie jedynowładztwa. Władza spoczywająca w rękach jednego, odpowiedzialnego człowieka jest gwarantem utrzymania ładu w państwie i prowadzenia pokojowej polityki zarówno wewnętrznej, jak i zewnętrznej. Wartym uwagi źródłem antycznym dostarczającym informacji na temat panowania Augusta jest także Historia rzymska Wellejusza Paterkulusa. Kompendium podzielone jest na dwie części, w których wyraźny jest podział na dwie epoki:

Z chwilą bowiem, gdy wygasł lęk przed Kartaginą i zniknął współzawodnik we władztwie nad światem, Rzymianie już nie krok po kroku, ale wprost w karkołomnym biegu porzucili drogę cnoty na rzecz występku ${ }^{17}$ [tłum. E. Zwolski].

Podobnie jak wzmiankowany wyżej Florus, Wellejusz Paterkulus uznaje upadek Kartaginy za ważną cezurę w rzymskich dziejach. Podczas gdy pierwszy okres charakteryzuje się skromnością, uczciwością i rzetelnością, w drugim na pierwszy plan wysuwa się upadek wojskowej dyscypliny i moralności społeczeństwa (Lewandowski 2007: 245). Dzieło Paterkulusa jest zwięzłe, skoncentrowane na wybitnych jednostkach (Dziuba 2004: 215). Dla współczesnych badań nad

${ }^{14}$ Pax Romana nie wiązała się explicite $\mathrm{z}$ zaniechaniem wojen toczonych $\mathrm{z}$ wrogami zewnętrznymi. August przez cały okres swojego panowania prowadził walki mające na celu zapewnienie bezpieczeństwa i stabilizację granic. Konflikty toczyły się z plemionami na zachodzie, na ogromnych terenach aż po Dunaj i Łabę oraz sporadycznie na Wschodzie. Dowództwo nad legionami sprawował nie tylko sam August, ale także osoby zaufane, członkowie rodziny cesarskiej (stanowiący tzw. domus Augusta). Byli to m.in. Agryppa, Marcellus, Tyberiusz, Druzus oraz wnukowie Augusta: Gajusz i Lucjusz. Cf. Sajkowski 2004: 369-382; Jończyk 2015: 27; Weinstock 1960.

${ }_{15}$ Flor. 2, 14, 5-6: Gratulandum tame nut in tanta perturbation est, quod potossimum ad Octavium Caesarem Augustum summa rerum redit, qui sapientia sua atque sollertia perculsum undique ac perturbatum ordinavit imperii corpus, quod haud dubie numquam coire et consentire potuisset, nisi unius praesidis nutu quasi anima et mente regeretur.

${ }^{16} C f$. Liv. Per. 134.

${ }_{17}$ Vell. 2, 1: quippe remoto Carthaginis metu sublataque imperii aemula non gradu, sed praecipiti cursu a virtute descitum, ad vitia transcursum; vetus disciplina deserta, nova inducta; in somnum a vigiliis, ab armis ad voluptates, a negotiis in otium conversa civitas. 
tradycją i historią antyczną jest ono ważne, nie tylko dlatego, że jest jedynym zachowanym opisem wczesnego pryncypatu przedstawionym przez naocznego świadka ${ }^{18}$. Istotny jest również fakt, że uznaje się je za etap przejściowy między annalistyczną historiografią powstającą $\mathrm{w}$ okresie republiki, a pisarstwem historycznym doby cesarstwa (Górska 2012: 7). Rodzajem pomostu między czasami republikańskimi a cesarstwem staje się w jego relacjach virtus (Balmaceda 2014: 344). Na temat samego Augusta i okresu jego władzy wypowiada się pozytywnie:

Wszystkim następnie, o co ludzie mogą błagać bogów i co bogowie mogą zsyłać ludziom, o czym można zamarzyć i czego dostąpić w szczęściu, August po swoim powrocie do Rzymu obdarzył rzeczpospolitą, naród rzymski i świat. W dwudziestym roku okiełznano szał wojen domowych, uśmierzono wrogów zewnętrznych. Ucichł szczęk oręża, wszędzie zapanował pokój. Prawa odzyskały moc, sądy powagę, senat dostojeństwo. Władzę urzędników sprowadzono do poprzednich ram, dobierając jedynie dwu pretorów do istniejących ośmiu. Wskrzeszono dawną, uświetnioną tradycją formę ustroju republikańskiego. Rolnik wrócił na pole, kapłan do świątyni. Ludzie znów poczuli się bezpieczni, przestali drżeć o swoje mienie ${ }^{19}$ [tłum. E. Zwolski].

Ocena działań podjętych przez cesarza, podobnie jak cech, którymi się charakteryzował, jest w relacji Paterkulusa bardzo praktyczna. Cesarz, który od wczesnej młodości odznaczał się wyjątkowymi zdolnościami, przywrócił dawny spokój i ład w państwie.

Zdaniem Tacyta monarchia była optymalną formą rządów (Tac. Hist. 1, 1, 1.), a władcę cechować powinny moderatio i odrzucenie skrajności. Podobnie jak w przekazie Florusa, obok przestrzegania norm prawnych kluczowe jest zachowywanie dawnej obyczajności. Człowiek jest jednostką i głównym faktorem Tacytowej historii. Postawa moralna owej jednostki ma zatem wpływ na losy świata (Lewandowski 2007: 297-298). W dziele historyka zauważyć można, że społeczeństwo obawiało się nowych rządów, jakie miały nastać po śmierci Augusta:

[...] każdy się oglądał na rozkazy księcia, wolny na razie od troski, póki August w kwitnących latach, podtrzymywał siebie, swój dom i pokój. Lecz gdy jego późna już starość poczęła nadto trapić niemoc fizyczna, a bliski zgon otwierał pole nowym nadziejom [...] największa

${ }^{18}$ Kwestią dyskusyjną pozostaje obiektywizm Paterkulusa. Problemem w jego ocenie staje się silne zretoryzowanie dzieła i jego panegiryczny charakter, który skłania część badaczy, by traktować jego relacje jako fałszywe i tym samym niegodne uwagi (Syme 1978: 45-63; Richardson 2012: 250).

${ }_{19}$ Vell. 2, 89: Nihil deinde optare a dis homines, nihil dii hominibus praestare possunt, nihil voto concipi, nihil felicitate consummari, quod non Augustus post reditum in urbem rei publicae populoque Romano terrarumque orbi repraesentaverit. Finita vicesimo anno bella civilia, sepulta externa, revocata pax, sopitus ubique armorum furor, restituta vis legibus, iudiciis auctoritas, senatui maiestas, imperium magistratuum ad pristinum redactum modum, tantummodo octo praetoribus adlecti duo. Prisca illa et antiqua rei publicae forma revocata. Rediit cultus agris, sacris honos, securitas hominibus, certa cuique rerum suarum possessio; leges emendatae utiliter, latae salubriter; senatus sine asperitate nec sine severitate lectus. 
bezsprzecznie część o zagrażających panach różne rozsiewała plotki: że Agrypa, brutal i rozsierdzony zhańbieniem, ani swym wiekiem, ani znajomością praw nie podoła tak wielkiemu ciężarowi; że Tyberiusz Nero wprawdzie dojrzały latami i wypróbowany wojownik, lecz pełen dawnej i dziedzicznej w rodzie Klaudiuszów pychy; wiele się też ujawnia, choć przytłumionych, oznak jego okrucieństwa"20 [tłum. S. Hammer].

Zaangażowanie Augusta w sprawy państwa wysoko ocenia również Swetoniusz. Cesarski biograf, którego dzieło - Żywoty Cezarów, ma ogromne znaczenie w procesie rekonstrukcji historii (Wolski 1987: 17-18), ceniony jest za erudycję, daleko posunięty obiektywizm oraz umiejętne zestawienie i przedstawienie faktów zebranych z różnych źródeł w sposób bezstronny i pragmatyczny. Przedstawiona przez niego historia jest ponadto pozbawiona ornamentyki retorycznej i ujęcia dramatycznego (Lewandowski 2007: 337). Choć w żywocie Augusta biograf nie przemilczał aspektów negatywnych ${ }^{21}$ wspominając np. o cudzołóstwie, zorganizowanej w czasie niedostatku i głodu uczcie zwanej bankietem „,dwunastu bogów" (Suet. Aug. 69) czy zemście na tłumach wrogów w Perugii, ogólna ocena rządów i postawy Augusta jest pozytywna:

Co do innych dziedzin życia, pewne jest, że okazywał najwyższą wstrzemięźliwość oraz prowadził nieposzlakowany tryb życia bez śladu jakiejkolwiek wady ${ }^{22}$ [tłum. J. Niemirska-Pliszczyńska].

Swetoniusz opisuje Augusta jako człowieka z boskim pierwiastkiem podkreślając ważną rolę jaką pełnił dla społeczeństwa, którym rządził²3. Nawet przypadki okrucieństwa władcy przedstawia w takim kontekście, że ich okoliczności i cele pozostają drugoplanowymi, a cała uwaga koncentruje się na innych wydarzeniach, które potwierdzają jego łaskawość (Cochran 1980: 190). Swetoniusz buduje swoje oceny w oparciu o pewien schemat, w którym wskazać można np.: odpowiedzialność, powściągliwość, siłę charakteru, etykę finansową, lojalność czy zaangażowanie w politykę wewnętrzną i zewnętrzną (Cochran 1980: 192-194, 197). Wymienione kategorie zastępują $\mathrm{w}$ jego relacjach układ chronologiczny - znany z innych

${ }^{20}$ Tac. Ann. 1, 4: omnes exuta aequalitate iussa principis aspectare, nulla in praesens formidine, dum Augustus aetate validus seque et domum in pacem sustentavit. postquam provecta iam senectus aegro et corpore fatigabatur, aderatque finis et spes novae (...) pars multo maxima inminentis dominos variis rumoribus differebant: trucem Agrippam et ignominia accensum non aetate neque rerum experientia tantae moli parem, Tiberium Neronem maturum annis, spectatum bello, sed vetere atque insita Claudiae familiae superbia, multaque indicia saevitiae, quamquam premantur, erumpere.

${ }^{21}$ Przekazuje np., że: „We wczesnej młodości naraził się na niesławną opinię z powodu jakoby różnorodnych występków. Sekstus Pompejusz ścigał go zarzutem zniewieściałości, M. Antoniusz zarzucił mu, że usynowienie przez wuja swej matki zawdzięcza zasługom w roli kochanka. Również brat Marka, Lucjusz, podnosi zarzut, jakoby swą cnotę męską, uszczkniętą nieco przez Cezara, sprzedał z kolei Aulowi Hircjuszowi w Hiszpanii za trzysta tysięcy sestercjów [...]". Suet. Aug. 68 [tłum. J. Niemirska-Pliszczyńska].

${ }^{22}$ Suet. Aug. 72, 1: In ceteris partibus vitae continentissimum constat ac sine suspicione ullius vitii.

${ }^{23}$ Wart uwagi jest w tym miejscu artykuł Wardle 2012. 
przekazów historycznych - dając odbiorcy możliwość zestawienia i porównania każdego z władców. Należy podkreślić, że biograf w swoich relacjach koncentruje się na głównej postaci i przekazuje fakty (Lewandowski 2007: 334) ${ }^{24}$. Skupia się przy tym na szczegółach: osobistych, osobliwych czy zawiłych, pokazując pewnego rodzaju niezależność od poprzedników (Syme 1980: 111) i oryginalność. Analiza dzieła Swetoniusza pozwala dostrzec rzadkie w literaturze antycznej dążenie do skrupulatnego przekazu opartego na pierwszorzędnych źródłach, takich jak autobiografie cesarzy, ich mowy i listy czy tajne dokumenty, do których miał dostęp jako wysoki urzędnik ab epistulis (Wolski 1987: 17). Choć zarzuca się mu obecnie nieumiejętne wartościowanie materiału i przypadkowość opisu mniej lub bardziej ważnych wydarzeń, w ujęciu całościowym Swetoniusz oceniany jest pozytywnie. Fakty, które przedstawia w przypadku następców Augusta, stawiają ich w niekorzystnym świetle, przez co uwydatnia się podział na władców pozytywnych i negatywnych. Jako sprawujący najwyższą władzę winni byli przestrzegać obowiązujących zasad i pozostawać (choć w pewnym stopniu) przykładnymi obywatelami. Rzeczywistość, szczególnie w okresie schyłku cesarstwa rzymskiego, była jednak inna.

Cesarz Tyberiusz - kwestor, sprawujący urząd konsula, który powoli stawał się głównym dowódcą wojsk Augusta, popadł w niełaskę cesarza, w wyniku czego w roku 6 p.n.e. wycofał się z działalności publicznej, udając się na dobrowolne wygnanie na wyspę Rodos. Przez kilka lat August sprzeciwiał się powrotowi pasierba z wyspy. Do władzy Tyberiusz doszedł w 14 r. n.e. (po śmierci Oktawiana Augusta), panował do 16 marca 37 r. n.e. W relacji Wellejusza Paterkulusa, sam władca ${ }^{25}$, jak i okres jego panowania przedstawione są pozytywnie, wręcz idealnie. W swoim dziele podkreśla, że pryncypat został wprowadzony nie tylko celem przywrócenia ładu i porządku w państwie, lecz także odrodzenia tego, co najcenniejsze dla Rzymian - czyli virtus (Balmaceda 2014: 343). Panowanie Tyberiusza było okresem, w którym państwo działało sprawnie, a poszczególne jego organy odzyskały powagę i wiarygodność. Na pierwszy plan wysuwają się tym samym wartości takie jak: auctoritas, gravitas, fides czy industria (Górska 2012: 13). Sam cesarz opisywany jest w Historii rzymskiej epitetami wartościującymi, np. eminentissimus, fama fortunaque celeberrimus i porównywany z Augustem: aequatus Augusto (Górska 2012: 15). Paterkulus podkreśla jego przywiązanie do wartości rodzinnych, troskę o żołnierzy (cura/ providentia), należy jednak pamiętać, że dzieło opisuje wydarzenia, które miały miejsce w stosunkowo dobrych latach panowania Tyberiusza, tj. przed spiskiem Sejana. W opinii części badaczy przekaz ten jest prawdziwszy od pesymistycznego w odbiorze opisu Tacyta (Lewandowski 2007: 247). Swetoniusz akcentuje, że Tyberiusz znany był z surowego przestrzegania karności wojskowej i niebywałej skromności (vir probus):

${ }^{24}$ Są to kwestie, które wyraźnie odróżniają go np. od Plutarcha, który podając materiał biograficzny uwzględnia postaci drugorzędne; ma na celu pokazanie przykładów, które mają uczyć człowieka bycia lepszym (historiografia jako magistra vitae). Lewandowski 2007: 334.

${ }^{25}$ Vell. 2, 94; 2, 99; 2, 103-106; 2, 113-114. 
[...] okazywał w początkach władzy wielką uprzejmość i zachowywał się prawie jak człowiek prywatny. $Z$ rozlicznych zaszczytów, jakie mu ofiarowywano, przyjął zaledwie kilka i to skromnych [...] zabronił wznoszenia na swoją cześć świątyń, wyznaczania oddzielnej służby religijnej dla swojego bóstwa, kapłanów, wystawiania także posągów i popiersi bez swojego pozwolenia ${ }^{26}$ [tłum. J. Niemirska-Pliszczyńska]

Biograf przekazuje, że Tyberiusz był człowiekiem cierpliwym, brzydził się pochlebstwem, dbał o państwowe finanse. Poświadcza ponadto grabieże, jakich miał się dopuszczać cesarz, a także o jego seksualne przyzwyczajenia, np. kiedy nauczał młodych chłopców aby podczas kąpieli niczym rybki krążyli między jego udami i podpływając podniecali go językiem lub podgryzieniami. Jego nienawiść w stosunku do krewnych była naruszeniem rzymskiej zasady pietas ${ }^{27}$. Nie żywił ojcowskiego przywiązania do synów: Druzusa i Germanika - tym ostatnim wręcz pomiatał. Żonie Julii - pozostającej na wygnaniu - zakazał opuszczania domu i obcowania z ludźmi. Z czasem ukazało się jego okrucieństwo, które było zaprzeczeniem wszystkich kluczowych rzymskich virtutes (Suet. Tyb. 61):

Żaden dzień nie minął bez zgładzenia człowieka, nawet religią zastrzeżony lub święty. Wymierzano karę śmierci nawet w dniu Nowego Roku. Oskarżano i skazywano wielu wraz z dziećmi. Nawet dzieci stawały się oskarżycielami. Zabroniono obchodzić żałobę rodzinom skazanych na śmierć. Uchwalono nadzwyczajne nagrody dla oskarżycieli, niekiedy dla świadków. Nie odmówiono wiary żadnemu z donosicieli. Wszelki zarzut uważano za powód do kary śmierci, nawet kilka najniewinniejszych słów [...]. Podsądni, wzywani na rozprawę dla obrony, albo w domu zadawali sobie rany, pewni wyroku skazującego oraz pragnąc uniknąc tortur i hańby, albo pośrodku kurii zażywali truciznę. Jednak opatrywano im rany i na wpół żywych i jeszcze drgających wleczono do więzienia. Wszystkich bez wyjątku skazańców zrzucano ze Schodów Germońskich i wleczono na haku. Jednego dnia zrzucono tak i zawleczono dwadzieścia ofiar, wśród nich kobiety i dzieci ${ }^{28}$ [tłum. J. Niemirska-Pliszczyńska].

Schemat, na którym Swetoniusz buduje swoje biografie ulega zmianie w przypadku kolejnych opisów rzymskich władców. Odchodzi w nich od porównania,

${ }^{26}$ Suet. Tyb. 26: Verum liberatus metu civilem admodum inter initia ac paulo minus quam privatum egit. Ex plurimis maximisque honoribus praeter paucos et modicos non recepit [...]. Templa, flamines, sacerdotes decerni sibi prohibuit, etiam statuas atque imagines nisi permittente se poni.

${ }^{27}$ Idea obowiązku pełnionego wobec rodziców, ojczyzny oraz bogów. Jej zróżnicowana natura sięga prawdopodobnie czasów wczesnej Republiki. Kult pietas odbywał się w Rzymie w świątyniach na Forum Holitorium i Circum Flaminium. Cf. Berdowski 2014: 143-145; Gryksa 2015: 218. Różnorodne odniesienia znaczeniowe i ideologiczne antycznej pietas cf. Garrison 1992.

${ }^{28}$ Suet. Tyb. 61: Nullus a poena hominum cessavit dies, ne religiosus quidem ac sacer; animadversum in quosdam ineunte anno novo. Accusati damnatique multi cum liberis atque etiam a liberis suis. Interdictum ne capite damnatos propinqui lugerent. Decreta accusatoribus praecipua praemia, nonnumquam et testibus. Nemini delatorum fides abrogata. Omne crimen pro capitali receptum, etiam paucorum simpliciumque verborum. (...) Citati ad causam dicendam partim se domi vulneraverunt certi damnationis et ad vexationem ignominiamque vitandam, partim in media curia venenum hauserunt; et tamen conligatis vulneribus ac semianimes palpitantesque adhuc in carcerem rapti. Nemo punitorum non in Gemonias abiectus uncoque tractus, viginti uno die abiecti tractique, inter eos feminae et pueri. 
w którym centralną osią są sprawy publiczne versus prywatne (jak w przypadku biografii Cezara i Augusta), na rzecz dychotomii dobro - zło (Hurley 2011: xxii). Znany ze wzniecania do siebie powszechnej życzliwości Kaligula, do pewnego momentu swojej władzy zyskiwał sobie przydomki ,pobożnego”, ,syna obozu”, „ojca wojsk” czy „najlepszego i największego Cezara”. Później jednak - zgodnie z przekazem Swetoniusza - zaczęły nim kierować pycha, złośliwość, okrucieństwo i zawiść. Strącił posągi sławnych mężów wzniesione przez Augusta, odebrał najzacniejszym obywatelom stare odznaki rodowe: Torkwatusowi łańcuch ${ }^{29}$; Cyncynatowi pukiel włosów $^{30}$; Gnejuszowi Pompejuszowi przydomek Wielkiego ${ }^{31}$. Co więcej:

Rozmiarami rozrzutności przeszedł wszystkich marnotrawców [...] wybudował dziesięciorzędowce liburnijskie. Miały one rufy wysadzane drogimi kamieniami, różnobarwne żagle, rozległe termy, portyki, jadalnie, rosły na nich krzewy winnej latorośli i drzewa owocowe różnego gatunku [tłum. J. Niemirska-Pliszczyńska].

W potrzebie uciekał się do grabieży, stosując przeróżne rodzaje fałszywych oskarżeń, licytacji i podatków. Swetoniusz dodaje, że nawet podczas odpoczynku i zabawy okazywał okrucieństwo w czynach i słowach:

Często podczas śniadania lub hulanki przypatrywał się, jak torturowano badanych nie na żarty podsądnych albo jak żołnierz biegły w sztuce katowskiej ścinał głowy skazańcom wleczonym na chybił trafił z więzienia. W Puteolach podczas poświęcenia mostu jego własnego pomysłu najpierw zaprosił do siebie liczną publiczność z wybrzeża, potem nagle wszystkich kazał zrzucić w morze. Niektórych czepiających się steru spychano do morza na jego rozkaz drągami i wiosłami ${ }^{32}$ [tłum. J. Niemirska-Pliszczyńska].

Cytowany wyżej passus kontrastuje z postulowanymi cechami vir Romanus, jakimi były w rzymskiej tradycji humanitas i clementia, dotyczącymi w szczególności traktowania wrogów i jeńców wojennych (Morgan 2007: 32). W przekazie

${ }^{29}$ Przydomek Torquatus od łacińskiego torques (łańcuch, naszyjnik) został nadany Tytusowi Manliuszowi, który w czasie najazdu Galów w 361 r. p.n.e. pozbawił pewnego Gala torquesu. Od tej pory przydomek przysługiwał członkom rodu Manliuszów aż do jego wygaśnięcia. Cf. Gajusz Kaligula (Swetoniusz 1987: 191, przyp. 68).

${ }^{30}$ Przydomek Cincinnatus (cincinnus - lok włosów) - oznaczający osobę o bujnych puklach. Pierwszym przedstawicielem rodu, którego obdarzono tym przydomkiem był Lucius Quinctius, dyktator 458 p.n.e. Cf. Gajusz Kaligula (Swetoniusz 1987: 191, przyp. 69).

${ }^{31}$ Gnejusz Pompejusz Magnus - potomek triumwirów: Pompejusza i Krassusa. Ojciec na część znamienitego przodka nazwał go Gnejuszem Pompejuszem Wielkim, czym naraził go na niełaskę cesarza Kaliguli. Kaligula zabronił Gnejuszowi używania przydomka Wielki (Magnus) i nie skazał go na śmierć tylko dlatego, że ten był jeszcze chłopcem, co potwierdza Kasjusz Dio Kokcejanus (Historia LX 5). Pełne imię w 41 roku n.e. przywrócił Gnejuszowi cesarz Klaudiusz.

${ }^{32}$ Suet. Calig. 32: Saepe in conspectu prandentis vel comisantis seriae quaestiones per tormenta habebantur, miles decollandi artifex quibuscumque e custodia capita amputabat. Puteolis dedicatione pontis, quem excogitatum ab eo significavimus, cum multos e litore invitasset ad se, repente omnis praecipitavit, quosdam gubernacula apprehendentes contis remisque detrusit in mare. 
biografa Kaligula jest postacią przedstawioną w sposób surowy. Dla Swetoniusza cesarz jest potworem ${ }^{33}$ (Katz 1972: 224). Sylwetka władcy znana jest współczesnym badaczom także z przekazów Kasjusza Dio, Józefa Flawiusza ${ }^{34}$ i Filona ${ }^{35}$. Część badaczy traktuje zachowane na jego temat informacje jako wystarczające, by podjąc debatę nad psychicznym stanem zdrowia cesarza. Wśród historyków nie brak opinii, że pogorszenie kondycji psychicznej władcy i zmiana jego usposobienia może być związana $\mathrm{z}$ chorobą, na którą zapadł $\mathrm{w}$ październiku 37 roku. Jego szaleństwo, czy też „mania” (obecnie uchodzące za terminy, które interpretować należy z ostrożnością), kojarzone są z różnymi chorobami, takimi jak: epilepsja (Suet. Calig. 50, 2), tyreotoksykoza, psychopatia, załamanie nerwowe czy schizofrenia, a w ostatnich latach temat był wielokrotnie poruszany przez badaczy (Sidwell 2010: 183). W literaturze naukowej pojawiają się także opinie, według których na stan zdrowia Kaliguli wpływ mogły mieć wydarzenia z przeszłości ${ }^{36}$. Próby usystematyzowania dostępnych informacji zachowanych w źródłach antycznych nie przynoszą jednak ostatecznej odpowiedzi na zależność choroby Kaliguli z jego późniejszym zachowaniem. Jakiekolwiek stwierdzenia z punktu widzenia medycznego czy psychoanalitycznego nie są możliwe, ponadto analizując relacje historiografów antycznych brać należy pod uwagę kontekst historyczno-polityczny i relacje pisarzy z ówczesną władzą (Sidwell 2010: 205). Cytowane wyżej passusy potwierdzają skłonność Kaliguli do naruszania zasad sprawiedliwości, łaskawości czy odpowiedniego zarządzania finansami, którymi kierować się powinien władca. Naruszenie wspomnianych postulowanych cech już w starożytnych relacjach rzucało na cesarza negatywne światło, a współcześnie nadal stanowi przedmiot dyskusji nad oceną jego postaci.

Dychotomiczny obraz cesarza przedstawiony jest również w przypadku Klaudiusza. Swetoniusz opisuje go jako człowieka skromnego i przystępnego (Claud. 12), sprawiedliwego (Claud. 14) choć z tendencją do nierównego i porywczego rozstrzygania spraw sądowych (15), dbającego troskliwie o bezpieczeństwo i wyżywienie Rzymu (Claud. 18), bojaźliwego i nieufnego (Claud. 35). Podkreśla, że z natury był okrutny i żądny krwi:

Kazał stosować tortury podczas śledztwa i wymierzać kary za morderstwa w rodzinie natychmiast i w swojej obecności [...]. Podczas wszelkich igrzysk gladiatorskich, czy

${ }^{33}$ Suet. Calig. 22, 1: Hactenus quasi de principe, reliqua ut de monstro narranda sunt.

${ }^{34}$ Biografia Kaliguli przedstawiona przez Józefa Flawiusza jest prawdopodobnie kopią innego, nieznanego źródła. Przypuszcza się, że jego autorem mógł być Selwiliusz Nonianus (Syme 1964: 408-424).

${ }^{35}$ Każdy z nich odniósł się w swoich relacjach do stanu umysłu cesarza i jego trudnego charakteru. Vide: Joseph. AJ. 19, 193; Dio 59, 4, 1 et 59, 23, 4; Tac. Ann. 13, 3, 2 (turbata mens); Philo. Leg. 4, 22.

${ }^{36}$ Za przykład podaje się np. lęk separacyjny wywołany rozłąką Kaliguli od jego rodziców, która trwać miała około 18 miesięcy (Ferrill 1991: 34). Argumenty Ferrilla nie są jednak oceniane jako przekonujące (Sidwell 2010: 188). 
przez siebie wydawanych, czy przez kogokolwiek innego, polecał mordować nawet tych, którzy przypadkowo się potknęli, nawet sieciarzy, aby widzieć twarze konających ${ }^{37}$ [thum. J. Niemirska-Pliszczyńska].

Organizując widowiska cesarz starał się zyskać przychylność widzów. Za najsłynniejsze uznawana jest niewątpliwie naumachia, wystawiona na jeziorze Fucinus. Uchodziło ono za źródło malarii i przeznaczone było do osuszenia. Wcześniej jednak cesarz postanowił wykorzystać je jako naturalną scenerię do przedstawienia historycznego starcia między flotami rodyjską i sycylijską. Wydarzenie zorganizowano na szeroką skalę (przekazywana w źródłach liczba uczestników - skazańców - sięga nawet dziewiętnastu tysięcy), a ważnym jego momentem był okrzyk (Have imperator, morituri te salutant) wydany przez marynarzy mających nadzieję na ułaskawienie (Epplett 2019: 88, cf. Suet. Claud. 21, 6). Odpowiedź ze strony cesarza (Claud. 21, 6: aut non) skutkowała opóźnieniem w rozpoczęciu bitwy, co rozgniewało Klaudiusza. Ostateczny los jeńców nie jest znany, bowiem informacje na ten temat w źródłach są sprzeczne ${ }^{38}$.

Barwną pod względem behawioralnym postacią jest także Neron. Początkowe lata jego panowania, określane przez badaczy mianem quinquennium Neronis, uznawano za jeden z najlepszych okresów rzymskiej historii. Był to czas, w którym cesarz pozostawał pod wpływem Seneki i Sekstusa Afraniusa Burrusa ${ }^{39} \mathrm{i}$ wiązano z nim ogromne nadzieje na przyszłość (Karakasis 2018: 8). Początkowo zamierzał on kierować się politycznymi wskazaniami Augusta, z czasem wkroczył jednak na drogę występku, a jego seksualne ${ }^{40}$ dewiacje (obok innych naruszeń) ukierunkowują odbiorcę antycznych relacji do formułowania negatywnej oceny jego zachowania:

Swoim ciałem kupczył tak szczodrze, że nie tylko splamił rozpustą prawie wszystkie jego części, lecz wymyślił jeszcze jakby nowy rodzaj zabawy. Oto przebrany w skórę dzikiego zwierzęcia wypadał z klatki i rzucał się na organy płciowe mężczyzn i kobiet przywiązanych do słupa ${ }^{41}$ [tłum. J. Niemirska-Pliszczyńska].

37 Suet. Claud. 34: Tormenta quaestionum poenasque parricidarum repraesentabat exigebatque coram. [...] Quocumque gladiatorio munere, vel suo vel alieno, etiam forte prolapsos iugulari iubebat, maxime retiarios, ut exspirantium facies videret.

${ }^{38}$ Cf. Dio 61, 33, 3-4; Tac. Ann. 12, 56, Suet. Claud. 21, 7.

39 Okres quinquennium Neronis datowany jest przez większość współczesnych badaczy na lata 54-59. Część opowiada się jednak za jego przesunięciem do roku 62 (57-62), w którym umiera Sekstus Afraniusz Burrus, a Seneka zostaje zwolniony ze swych politycznych obowiązków wobec cesarza. $C f$. Faversani 2014: 158.

${ }^{40}$ Neron, podobnie jak Domicjan i Kaligula, nie wykazywał szczególnego zainteresowania pięknem kobiet. Podczas podróży do Grecji poślubił dwóch mężczyzn jednocześnie. W związku ze Sporusem pełnił rolę mężczyzny, z kolei w stosunkach z Doryforosem był kobietą.

${ }^{41}$ Suet. Nero 29: Suam quidem pudicitiam usque adeo prostituit, ut contaminatis paene omnibus membris novissime quasi genus lusus excogitaret, quo ferae pelle contectus emitteretur e cavea virorumque ac feminarum ad stipitem deligatorum inguina invaderet. 
Zaspokoiwszy swoją żądzę miał oddawać się wyzwoleńcowi Doryfosowi, którego ostatecznie zgładził (miał sprzeciwiać się zaślubinom Nerona z Poppeą, vide: Tac. Ann. 14, 65). Sfera virtus Romana w odniesieniu do zachowań seksualnych zawarta jest w łacińskim (obszernym we współczesnym pojęciu) terminie pudicitia. Rebeca Langlands w swojej publikacji kategoryzuje wspomnianą rzymską cnotę odwołując się m.in. do uosobionej cechy moralnej, siły moralnej określanej jako samoregulacja wewnętrzna (utożsamiana z grecką sōphrosyne $e^{42}$ ), koncepcję porównywalną ze współczesnym wstydem (Langlands 2006: 31). Powszechne zepsucie, jakie daje się zaobserwować wśród młodych mężczyzn i kobiet, stanowi punkt wyjścia dla seksualnych wykroczeń cesarza. Deprawacja następuje zarówno w sferze religijnej, jak i w traktowaniu tradycyjnego, dawnego pojęcia instytucji małżeństwa (Langlands 2006: 356).

Neron, doskonale wykształcony, wielbiciel koni, znawca i pasjonat sztuki, niechlubnie zapisał się także na kartach historii chrześcijaństwa (Canfield 1913: 141-159) ${ }^{43}$. W nocy z 18 na 19 lipca 64 roku Rzym strawił pożar, obracając w pył blisko trzy czwarte miasta. Ogień udało się opanować po sześciu dniach. Opinia przypisuje wspomnianą klęskę szaleństwu Nerona, który z kolei winą za tragedię obarcza chrześcijan. Wśród mieszkańców Rzymu byli oni uznawani za mizantropów, ateuszy, i rozpustników oddających się orgiastycznym rytuałom (Pierrard 1984: 28-29). W nocy z 15 na 16 sierpnia w Rzymie ma miejsce jedno z najbardziej krwawych i okrutnych widowisk:

Schwytano więc naprzód tych, którzy tę wiarę publicznie wyznawali, potem na podstawie ich zeznań ogromne mnóstwo innych, i udowodniono im nie tyle zbrodnię podpalenia, ile nienawiść ku rodzajowi ludzkiemu. A śmierci ich przydano to urągowisko, że okryci skórami dzikich zwierząt ginęli rozszarpywani przez psy albo przybici do krzyżów, [albo przeznaczeni na pastwę płomieni i], gdy zabrakło dnia, palili się służąc za nocne pochodnie ${ }^{44}$ [tłum. S. Hammer].

Skala pożaru niosła za sobą poważne zmiany i konieczność znalezienia winnych. Cesarz początkowo starał się uspokoić wszelkie nieprzychylne pogłoski poprzez urządzanie religijnych ceremonii, podczas których chciał ułagodzić gniew bogów. Gdy jego działania nie przyniosły oczekiwanych rezultatów, zdecydował się skierować oskarżenia na chrześcijan (Griffin 2018: 181).

42 Jurewicz 2001: zdrowy rozum, rozsadek, umiarkowanie w żadzach, skromność, przyzwoitość, opanowanie.

${ }^{43}$ Wśród źródeł wskazujących Nerona jako prześladowcę chrześcijan należy wymienić także Tertuliana (Apologeticum 5, 21; Ad nationes 1, 7; Scorpiace 15, De praescriptione haereticorum 36) czy Orozjusza (Historia 7, 7).

${ }^{44}$ Tac. Ann. 15, 44: igitur primum correpti qui fatebantur, deinde indicio eorum multitudo ingens haud proinde in crimine incendii quam odio humani generis convicti sunt. et pereuntibus addita ludibria, ut ferarum tergis contecti laniatu canum interirent aut crucibus adfixi [aut flammandi atque], ubi defecisset dies, in usu[m] nocturni luminis urerentur. 
Próba przedstawienia dychotomicznego obrazu władców rzymskich, którzy z jednej strony charakteryzują się postulowanymi w przypadku osób sprawujących władzę cechami (vir probus/honestus/benevolus), z drugiej z kolei sadystyczny władca pokpiwający z ludzkiego losu i życia, pozwala spojrzeć na świat antyczny z nieco innej perspektywy. Przedstawione w niniejszym artykule passusy dzieł zostały dobrane celem ukazania kluczowych idei virtutes oraz zmian jakie zachodzily w sposobie ich traktowania i przestrzegania na przestrzeni wieków. Choć relacje pisarzy doby cesarstwa różnią się znacząco, a na przedstawioną przez nich ocenę panujących wpływ miała tradycja literacka, przyjęte wzorce i ówczesna sytuacja polityczno-społeczna, pozwalają przedstawić dualistyczny obraz panujących. Pozostawiają tym samym ważne świadectwo w odniesieniu do czynów i zachowań godnych pochwał czy negatywnych o wartości dydaktycznej. Należy pamiętać, że świadectwo realiów cesarskich rządów jest kombinacją wiernego prawdzie raportu, z elementami hiperbolizacji i pewnych domysłów. Rzeczywistość sensu stricto jest niemal zawsze niemożliwa do rozwikłania (Beard 2016: 371).

\section{Bibliografia}

\section{Teksty oryginalne}

Cicero M. Tulius (1890). Scripta quae manserunt omnia. Mueller, C.F.W. (red.). Lipsiae: Teubner. Florus (2012). Oeuvres. Transl. P. Jal. Paris: Les Belles Lettres.

Sallustius Crispus (1981). Bellum Iugurthinum. Kurfess, A. (red.). Leipzig: Velhagen \& Klasing. Suetonius Tranquillus C. (2003). De vita Caesarum libri VIII. Ihm, M. (red.). Lipsiae: Teubner. Tacitus P. Cornelius (1925). Annales. Goelzer, H. (red.). Paris: Les Belles Lettres.

Velleius Paterculus (1988). Historiarum ad M. Vinicium consulem libri duo. Watt, W.S. (red.). Leipzig: Bibliotheca Teubneriana.

\section{Przekłady}

Florus, L.A. (2006). Zarys dziejów rzymskich. Przeł. I. Lewandowski. Warszawa: Zakład Narodowy im. Ossolińskich.

Liwiusz Titus (1968). Dzieje Rzymu od założenia miasta. Ks. 1-5. Przeł. A. Kościółek. Wrocław: Zakład Narodowy im. Ossolińskich.

Salustius Gajus Crispus (2006). Sprzysiężenie Katyliny i wojna z Jugurta. Przeł. K. Kumaniecki. Wrocław: Drukarnia Trzaska.

Swetoniusz (1987). Żywoty cezarów. Przeł. J. Niemirska-Pliszczyńska. Wrocław: Zakład Narodowy im. Ossolińskich.

Tacyt (2004). Dzieła. T. 1-2. Przeł. S. Hammer. Warszawa: Czytelnik.

Wellejusz Paterkulus (1970). Historia rzymska. Przeł. E. Zwolski. Wrocław: Zakład Narodowy im. Ossolińskich. 


\section{Opracowania}

Ankersmit, F. (2002). Pochwała subiektywności. W: Domańska, E. (red.). Pamięć, etyka i historia. Angloamerykańska teoria historiografii lat dziewięćdziesiatych. Poznań: Wydawnictwo Poznańskie.

Balmaceda, C. (2014). „The Virtues of Tiberius in Velleius Histories”. Historia: Zeitschrift für Alte Geschichte. Bd. 63, H. 3. 340-363.

Baumann, R. (2006). Human Rights in ancient Rome. London: Routledge Classical Monographs.

Beard, M. (2016). SPQR. Historia starożytnego Rzymu. Przeł. N. Radomski. Poznań: Dom Wydawniczy Rebis.

Berdowski, P. (2014). Pietas erga patriam: Ideology and Politics in Rome in Early First Century BC. The Evidence from Coins and Glandae Inscriptae. W: Twardowska, K., Salamon M. et al. (red.). Within the Circle of Ancient Ideas and Virtutes. Kraków: Towarzystwo Wydawnicze „Historia Iagellonica".

Canfield, L.H. (1913). The Early Persecutions of the Christians, New York: University of Columbia.

Cochran, L.R. (1980). „Suetonius' Conception of Imperial Character”. Biography 3 (3). 189-201.

Dziuba, A. (2004). Curiositas w Historii rzymskiej Wellejusza Paterkulusa. Lublin: Wydawnictwo KUL.

Epplett, Ch. (2019). Gladiatorzy i walki z dzikimi zwierzętami na arenach. Kraków: Wydawnictwo Astra s.c.

Faversani, F. (2014). „Quinquennius Neronis e a ideia de um bom governo”. Phoînix 20-1. 158-177.

Ferrill, A. (1991). Caligula: Emperor of Rome. London: Thames and Hudson.

Garrison, J. (1992). Pietas from Vergil to Dryden. Pennsylvania: The Pennsylvania Stat. University Press.

Górska, M. (2012). „Obraz początków pryncypatu w II księdze Historii rzymskiej Wellejusza Paterkulusa na podstawie językowych wykładników wartościowania". Wratislaviensium Studia Classica olim Classica Wratislaviensia I (XXXII). 7-25.

Grethlein, J. (2013). Experience and Teleology in Ancient Historiography. Futures Past from Herodotus to Augustine. Cambridge: Cambridge University Press.

Griffin, M. (2018). Neron. Koniec dynastii. Oświęcim: Napoleon V.

Gryksa, E. (2015). „Śmierć jako pietas erga patriam w historiografii starożytnego Rzymu”. Littera Antiqua 10. 218-228.

Gryksa, E. (2017a). Obraz Rzymu u Florusa. Tarnów: Wydawnictwo Diecezji Tarnowskiej Biblos.

Gryksa, E. (2017b). Mira et incredibilia w rzymskich dziełach historiograficznych Florusa, Tacyta i Liwiusza. W: Wolny M., Chudzikowska-Wołoszyn M. (red.). Paradoksologia w starożytności i średniowieczu. Olsztyn: Zakład Poligraficzny Uniwersytetu Warmińsko-Mazurskiego.

Heck, D. (2009). „Problem filologii. Metoda filologiczna - dzisiaj?” Litteraria XXXVII. 7-18.

Hurley, D.W. (2011). Gaius Suetonius Tranquillus. The Caesars. Translated with Introductions and Notes by D.W. Hurley. Cambridge: Hackett Publishing Company.

Jończyk, Ł. (2015). Tyberiusz i Druzus jako wodzowie Augusta w świetle relacji Wellejusza Paterkulusa i Kasjusza Diona. W: Kowalski, H., Madejski P. (red.). Armia, systemy obronne i ideologiczno-religijne aspekty wojny w imperium rzymskim. Lublin: Wydawnictwo Uniwersytetu Marii Curie-Skłodowskiej.

Karakasis, E. (2018). T. Calpurnius Siculus. A pastoral Poet in Neronian Rome. Berlin: De Gruyter. Katz, R.S. (1972). „The Illness of Caligula”. The Classical World 65 (10). 223-225.

Langlands, R. (2006). Sexual Morality in Ancient Rome. Cambridge: Cambridge University Press.

Lewandowski, I. (2007). Historiografia rzymska. Poznań: Wydawnictwo Poznańskie.

Marincola, J. (1997). Authority and Tradition in Ancient Historiography. Cambridge: Cambridge University Press. 
Morgan, T. (2007). Popular Morality in the Early Empire. Cambridge: Cambridge University Press. Paschalis, M. (1997). Virgil's Aeneid: Semantic Relations and Proper Name. Oxford: Clarendon Press.

Paul, H. (2011). Hayden White. The Historical Imagination. Cambridge: Polity Press.

Pierrard, P. (1984). Historia kościoła katolickiego. Warszawa: PAX.

Pigoń, J. (1996). W kręgu pojęć politycznych Tacyta: libertas - moderatio. Wrocław: Wydawnictwo Uniwersytetu Wrocławskiego.

Polo, F.P. (2003). Dziejopisarstwo, mos maiorum i rzymska tożsamość. Poznań: Uniwersytet im. Adama Mickiewicza.

Richardson, J.S. (2012). Augustan Rome 44 BC to AD 14. Edinburgh: Edinburgh University Press.

Sajkowski, R. (2004). Domus Augusta-domus divina. W: Morawiecki, L., Berdowski, P. (red.). Ideologia i propaganda w starożytności. Rzeszów: Stowarzyszenie Literacko-Artystyczne „Fraza”.

Sidwell, B. (2010). „Gaius Caligula's Mental Illness”. The Classical World 103 (2). 183-206.

Syme, R. (1964). „The Historian Servilius Nonianius”. Hermes 92. 408-424.

Syme, R. (1978). „Mendacity in Velleius”. American Journal of Philology 99. 45-63.

Syme, R. (1980). „Biographers of the Caesars”. Museum Helveticum 37 (2). 104-128.

Wardle, D. (2012). „Suetonius on Augustus as God and Man”. The Classical Quarterly 62 (1). 307-326.

Weinstock, S. (1960). „Pax and the Ara Pacis”. Journal of Roman Studies 50 (1-2). 44-58.

Wilkinson, S. (2012). Republicanism during the Early Roman Empire. London: Continuum.

Wolski, J. (1987). Swetoniusz - historyk. W: Swetoniusz. Żywoty Cezarów. Przeł. J. Niemirska-Pliszczyńska. Wrocław: Zakład Narodowy im. Ossolińskich.

Zanker, P. (1999). August i potęga obrazów. Poznań: Uniwersytet im. Adama Mickiewicza.

Zoch, P.A. (2012). Ancient Rome: An Introductory History. Oclahoma: University of Oclahoma Press.

dr Edyta Gryksa (Uniwersytet Śląski w Katowicach) - Assistant Professor in Department of Classical Philology at the University of Silesia in Poland. The Author of a monograph Florus' vision of Rome (Tarnów 2017) and co-author of Nemesianus in the ancient hunting tradition (written with Anna Kucz). Her interests focus on Roman historiography (especially in The Roman Empire) as well as on history and tradition of ancient military (Master thesis: Gladius and ensis in the Roman civilization). A member of the Polish Philological Association and the Roman Society. At present she is conducting a research on hunting and pastoral poetry (output of Grattius Faliscus and Calpurnius Siculus).

e-mail: edyta.gryksa@gmail.com 